\title{
Phytoremediation and Crude Oil Bioaccumulation Potential of Zea Mays L
}

\author{
${ }^{1}$ Ezeonu, Chukwuma Stephen \\ ${ }^{I}$ Department of Biochemistry, Federal University Wukari, Taraba State, Nigeria.
}

\begin{abstract}
The rate of biodegradation of crude oil under natural environment was examined. Crude oil contaminated soil was simulated. A quantity of $24 \mathrm{~kg}$ of the soil was divided into 3 groups of $8 \mathrm{~kg}$ each, consisting of soil samples contaminated with Petrol Hydrocarbon (PHC) in the concentrations of $5 \%, 10 \%$ and $20 \% \mathrm{w} / \mathrm{w}$. After a week of soil preparation, 6 viable Zea mays seeds were planted on each pot. Nurseries of the Zea mays seeds were also raised and used for transplanting were necessary. After 8 weeks of growth, bioaccumulation of crude oil in leaves of the Zea mays $L$ as well as the quantity of crude oil remaining in the contaminated soil were determined. The concentration of crude oil was extracted using $10 \mathrm{ml}$ of 1:1 Ethanol/Chloroform mixture to extract the crude oil from $1 g$ of each contaminated soil as well as Zea mays biomass cultivated on each contaminated soil was extracted at 8 weeks of studies. The result from the finding indicated that $5 \%, 10 \%$ and $20 \%$ (PHC) contaminated soils had $0.0023 \pm 0.00005 \mathrm{mg} / \mathrm{g}, 0.0016 \pm 0.0005 \mathrm{mg} / \mathrm{g}$ and $0.0022 \pm 0.0003 \mathrm{mg} / \mathrm{g}$ respectively of crude oil bioaccumulation in Zea mays cultivated in them. The percentage crude oil degradation from each soil test group was approximately $99 \%$.
\end{abstract}

Keywords: Petroleum Hydrocarbon, Contamination, Zea mays, Bioaccumulation, degradation.

\section{Introduction}

Bioaccumulation is the process by which terrestrial organisms such as plant and soil invertebrates accumulate and concentrate pollutants from the soil (Mackay and Roberts, 1985). Plants are known to take up numerous inorganic and organic contaminants and store them in various plant organs. With respect to specific contaminants in petroleum, limited research has been directed to assess the extent to which they are taken up by various plant species. According to Haghiri (1973), soybeans and wheat take cadmium up via roots from soil in a very efficient manner. Microbes do not have to be added in order for bioremediation to take place, most soil contains more than ten million naturally occurring (indigenous) microbes per gram that have adapted to live in that environment (Atlas, 1984). At least $10 \%$ of these microbes are capable of biodegrading petroleum hydrocarbons when the right conditions exist (Atlas, 1984). The ability of crop to germinate or grow on crude oil polluted soil is dependent on the level of crude oil spillage on soil (Odu, 1972). This means that a high level of crude oil pollution of the soil impairs germination of seedlings. Rowell (1977) stated that at low level of spillage e.g. one percent of oil contamination, germination may be delayed due to lack of moisture and hardening of soil structure. Moreover, at high contamination of soil, there may be no germination. Hence seed rotting will take place due to seeping of crude oil into the seeds through the outer integument. The interference of oil to soil air and water is another means of inhibiting seed germination. McGill (1976) noted that the toxic effect of crude oil coupled with poor aeration with wettability of the soil due to oil spillage results in poor seed germination. The recovery of soil fertility after an oil spill depends on a number of factors including the quantity spilled (McCown and Deneke, 1973). Phytoremediation is one major way of reclaiming crude oil contaminated soil. The essence of this work is to investigate the rate of degradation of crude oil after 8 weeks of spillage and cultivation of maize. Also the quantity of crude oil remaining in both the maize biomass and soil were investigated as indices of bioremediation of the contaminated soil.

\section{Plant Material and Crude Oil}

\section{Materials And Methods}

Viable Zea mays seeds were purchased from Ogige market Nsukka, and used in this experiment The test sample used in contaminating the soil samples was crude oil "Bonny" light (B-III Nigerian) obtained from the Department of Petroleum Resources (DPR), Port Harcourt.

\section{Experimental Design}

Forty kilograms $(40 \mathrm{~kg})$ of soil not previously cultivated were collected beside Biochemistry Postgraduate Laboratory, University of Nigeria, Nsukka. The soil was weighed; air/sun dried, stones and debris were removed manually. The soil was weighed out into five different soil microcosms of $8 \mathrm{~kg}$ each. These constituted two controls and three experimental variable samples. A quantity of $32 \mathrm{~kg}$ of the soil was spiked by mixing thoroughly with 1 litre of $1 \mathrm{M}$ solution of each of the salts $\left(\mathrm{K}_{2} \mathrm{SO}_{4}, \mathrm{CaCl}_{2}\right.$ and $\left.\mathrm{MgSO}_{4}\right)$. The spiked soil 
was divided into 4 groups of $8 \mathrm{~kg}$ each, consisting of Control B (spiked control) and the test samples. The test soil samples were contaminated with crude oil in the concentrations of $5 \%, 10 \%$ and $20 \% \mathrm{w} / \mathrm{w}$. Each of the soil samples was divided into 2 equal parts and placed in polythene planting bags. These planting pots containing the prepared soils for the control and experimental groups were then conveyed to Biochemistry Garden/Farm beside the Post Graduate Laboratory of the University of Nigeria, Nsukka and kept in labelled rows in duplicate after perforating the planting pots to allow for horizontal aeration and vertical leaching. They were kept for 1 week before the planting of seeds was carried out on them (soils). After a week of soil preparation 6 viable Zea mays seeds were planted on each pot. Nurseries of the Zea mays seeds were also raised and used for transplanting were necessary. After 8 weeks of growth, bioaccumulation of crude oil in leaves of the Zea mays L as well as the quantity of crude oil remaining in the contaminated soil was determined.

\section{Extraction of Crude Oil from Soil and Plant Materials}

The plant materials $1 \mathrm{~g}$ (ground leaves/stem of Zea mays) was carefully packed into the extractor (conical flasks). Extraction was carried out using chloroform/ethanol 1:1 as solvent. The extraction involved 1g of the ground Zea mays leaves and stems with $10 \mathrm{mls}$ of solvent agitated for 30 minutes using a horizontal shaker. The extracted crude oil from Zea mays $L$ of each experimental group in triplicate were placed in test tubes. The 8 weeks old crude oil contaminated soil was extracted using $10 \mathrm{ml}$ of 1:1 Ethanol/Chloroform mixture to extract the crude oil from $1 \mathrm{~g}$ of each soil sample. These were left at room temperature for 30 minutes and the optical density (absorbance) was read at the wavelength of $520 \mathrm{~nm}$ using Novasc spectrophotometer.

\section{Results}

Among the contaminated soil, Zea mays cultivated on the 20\% PHC (Petroleum Hydrocarbon) contaminated soil had plants with a value of $0.0022 \pm 0.0003 \mathrm{mg} / \mathrm{g}$ making up $0.33 \%$ of total crude oil contaminant of the soil had the least bioaccumulation of crude oil as seen in Table 1. Zea mays cultivated on $5 \%$ (PHC) contaminated soil with a value of $0.0023 \pm 0.00005 \mathrm{mg} / \mathrm{g}$ or $0.81 \%$ crude oil total contaminated soil exhibited the highest level of (PHC) crude oil bioaccumulation from the results shown in table 1, this was followed by Zea mays cultivated on 10\% (PHC) contaminated soil. The mean bioaccumulation of crude oil Zea mays cultivated in each group of soil contaminant was less than $1 \%$ and therefore quite negligible. This could be due to the rate of plant uptake of crude oil; it could dependent on the quantity of crude oil contaminant accessible to the roots of individual Zea mays plant. Thus, bioaccumulation is a factor which is important in removal of concentrated pollutant from the soil.

Table 1: Crude oil bioaccumulation in $\mathrm{mg} / \mathrm{g}$ of maize biomass after 8 weeks of growth.

\begin{tabular}{|c|c|c|c|c|c|}
\hline Test & $\begin{array}{l}\text { Group A: Crude oil } \\
\text { Bioaccumulation } \\
\text { (mg/g of maize). }\end{array}$ & $\begin{array}{l}\text { Group B: Crude Oil } \\
\text { Bioaccumulation } \\
(\mathrm{mg} / \mathrm{g} \text { of maize })\end{array}$ & $\begin{array}{l}\text { Group C } \\
\text { Crude oil } \\
\text { accumulation } \\
\text { (mg/g of maize) }\end{array}$ & Mean \pm S.D & $\begin{array}{l}\text { Percentage of } \\
\text { Crude oil } \\
\text { Bioaccumulated } \\
\text { in maize } \\
\end{array}$ \\
\hline $\begin{array}{l}5 \%(\mathrm{PHC}) \\
\text { Contaminated soil }\end{array}$ & 0.0023 & 0.0022 & 0.0023 & $0.0023 \pm 0.00005$ & 0.81 \\
\hline $\begin{array}{lr}10 \% & (\mathrm{PHC}) \\
\text { Contaminated soil }\end{array}$ & 0.0013 & 0.0013 & 0.0023 & $0.0016 \pm 0.0005$ & 0.34 \\
\hline $\begin{array}{l}20 \% \quad(\mathrm{PHC}) \\
\text { Contaminated } \\
\text { soil. }\end{array}$ & 0.0018 & 0.0025 & 0.0023 & $0.0022 \pm 0.0003$ & 0.33 \\
\hline
\end{tabular}

Mackay and Roberts (1985), stated that bioaccumulation is the process by which terrestrial organisms such as plant and soil invertebrates (eg. earthworm) accumulate and concentrate pollutants from the soil. This experiment showed minimal traces of bioaccumulation of crude oil. For the plant to grow, photosynthesis, transpiration, translocation of manufactured food (carbohydrate) as well as conduction of water and mineral salt and soil nutrient plays great roles. In the course of these complex processes, crude oil in soil are conducted along with water and soil nutrient and lost during photosynthesis, transpiration and respiration of the maize plant. Useful nutrients including decomposing crude oil and mineral salts could serve as nutrients needed during photosynthesis since crude oil could also be a source of carbon when decomposed. It also means that crude oil is conducted away from the soil by maize plant as means of phytoremediation and bioremediation of the contaminated soil. As McGill (1976) noted, the toxic effect of crude oil coupled with poor aeration with wettability of the soil due to oil spillage results in poor seed germination. Transplant of nursery was carried out in the second week of planting for those maize plants which could not germinate. Those that germinated as well as the transplants survived for 8 weeks even though all the maize experience stunted growth. The fact that crude oil bioaccumulation in Zea mays after 8 weeks of cultivation was minimal showed that there is a continuous removal of crude oil from soil on daily basis. The maize plant carries out metabolic activities in which a given 
quantity of crude oil along with soil water and nutrients are taken into the plant daily, metabolized and lost. In as much as metabolic activities take place in plant the rate of removal of crude oil as experienced by the plant is a function of the metabolic activity of the plant. Thus there might be no continuous bioaccumulation but rather bioaccumulation and simultaneous continuous removal of pollutants from the soil.

The quantity of crude oil remaining after 8 weeks from the soil cultivated with maize showed that each of the crude oil contaminated soil showed an average degradation rate of approximately $99 \%$ as shown in table 2 .

Table 2: Remaining crude oil in soil after 8 weeks of maize cultivation.

\begin{tabular}{|c|c|c|c|c|c|c|c|}
\hline Sample & $\begin{array}{l}\text { Group } \\
\text { A }\end{array}$ & $\begin{array}{l}\text { Group } \\
\text { B }\end{array}$ & $\begin{array}{l}\text { Group } \\
\text { C }\end{array}$ & $\begin{array}{l}\text { Mean Quantity } \\
\text { Remaining }(\mathrm{mg} / \mathrm{g}) \\
\text { Mean — S.D }\end{array}$ & $\begin{array}{l}\text { Initial Quantity } \\
\text { of crude oil in } \\
\text { soil immediately } \\
\text { after } \\
\text { contamination } \\
(\mathrm{mg} / \mathrm{g})\end{array}$ & $\begin{array}{l}\text { Quantity } \\
\text { Degraded } \\
(\mathrm{mg} / \mathrm{g})\end{array}$ & $\begin{array}{l}\text { Percentage } \\
\text { Degradation } \\
(\%)\end{array}$ \\
\hline $\begin{array}{l}5 \%(\mathrm{PHC}) \text { Contaminated } \\
\text { Soil }\end{array}$ & 0.0038 & 0.0020 & 0.0039 & $0.0032 \pm 0.0009$ & 0.285 & 0.282 & 98.97 \\
\hline $\begin{array}{l}10 \% \quad(\mathrm{PHC}) \\
\text { Contaminated Soil. }\end{array}$ & 0.0042 & 0.0059 & 0.0066 & $0.0056 \pm 0.0010$ & 0.470 & 0.464 & 98.72 \\
\hline $\begin{array}{l}20 \% \\
\text { (PHC)Contaminated } \\
\text { Soil. }\end{array}$ & 0.0073 & 0.0084 & 0.0087 & $0.0081 \pm 0.0006$ & 0.672 & 0.664 & 98.81 \\
\hline
\end{tabular}

After simulated contamination of the soil before cultivation, the crude oil extracted from the soil gave values of $0.285 \mathrm{mg} / \mathrm{g}, 0.470 \mathrm{mg} / \mathrm{g}$ and $0.672 \mathrm{mg} / \mathrm{g}$ for $5 \%$ (PHC) contaminated soil, $10 \%$ (PHC) contaminated soil and 20\% (PHC) contaminated soil. The quantities of crude oil remaining showed that $5 \%, 10 \%$ and $20 \%$ (PHC) contaminated soils after 8 weeks had $0.0032 \pm 0.0009 \mathrm{mg} / \mathrm{g}, 0.0056 \pm 0.0010 \mathrm{mg} / \mathrm{g}$ and $0.0081 \pm 0.0006$ $\mathrm{mg} / \mathrm{g}$ as seen in table 2 .

\section{Discussion}

Each of the percentage $(5 \%, 10 \%$ and $20 \%$ PHC) contamination indicated that very little quantities of crude oil remained in the soil after about 8 weeks of cultivating the polluted soil with Zea mays plant. This experiment was carried out during the 8 week of maize cultivation and 9th week of the post contamination of the soil. The results revealed that degradation of petroleum hydrocarbon took place as a result of the activities of weathering by plant root, the climate, water and micro-organisms. Hence biodegradation agents involved in crude oil spillage contaminated soil include: Zea mays via phytoremediation, weather (sun, rain, moisture, heat, etc) as well as micro-organism (DOE/PERF, 2002; Lombi et al, 2001). These factors and experimental results in this work are in total harmony with existing literatures.

\section{References}

[1]. Atlas, R.M and Bartha, R (1998). Fundamentals and Applications. In: microbial $\quad$ Ecology. $4^{\text {th }}$ edition. Benjamin / Cumming Publishing Company, Inc. California, USA, pp $523-530$.

[2]. DOE/PERF (2002). A Summary of the DOE/PERF Bioremediation Workshop.

[3]. Highiri, F.(1973). Cadmium uptake by plants. J. Environ. Qual. 2:93-95

[4]. Lombi, E., Zhao, F. J., Dunham, S. J., McGrath, S. P.(2001). Phytoremediation of heavy metal- contaminated soils: natural hyper-accumulation versus chemically enhancedphytoextraction. J. Environ. Qual. 30(6): 1919-1926.

[5]. Mackay, D.M. and Roberts, P.V.(1985). Transport of organic contaminants in groundwater. Environ. Sci. Technol. $19(5): 384$.

[6]. McCown, D. D and Deneke, F.J (1973). Plant germination and seedling growth as affected by the presence of crude petroleum, in Proc. Symp. Impact of Oil, Resources development of Northern Plant Communities, Inst. Of Arctic Biology, Univ. of Alaska, Fairbanks, Alaska pp 44-51.

[7]. McGill, W.B.(1976). An introduction to field personnel act of oil spills on soil and some general restoration and clean up procedures. Albert Institute of Petrology. AIP publisher, No. C-76-1.

[8]. Odu, C.T.T (1972). Microbiology of soils contaminated with petroleum hydrocarbon. Extent of contamination and some soil and microbial properties after contamination. J. Institute of Petroleum, pp 58, 201-204.

[9]. Rowell, M.J. (1977) The effect of crude oil spills on soils. In: The reclamation of agricultural soils after oil spills, J.A.Toogood (editor). Department of Soil Science, University of Alberta, Edmonton. pp 1-33. 